\title{
The Effects Of State Tort Provisions And Perceptions Of Litigation Risk On Malpractice Insurance
}

\author{
Mark Linville, (e-mail: linville@wsu.edu) Washington State University, Pullman
}

\begin{abstract}
This study is an empirical examination of the use of malpractice insurance by independent auditors. Higher insurance premiums are found in states that utilize the foreseeable third-party standard. Auditors who perceive higher litigation risk are found to be willing to bear higher insurance premiums and to opt for higher coverage. Overall, the results suggest that state tort provisions influence litigation risk and malpractice insurance is used to mitigate this risk. ${ }^{l}$
\end{abstract}

\section{Introduction}

udit litigation is an important topic in the academic and practitioner literature (see A Latham and Linville, 1998 or Palmrose, 1997 for a review of the literature). As litigation risk increases, the CPA firm must view each audit engagement (and other service offering) as a potential source of litigation. The CPA firm has several ways of managing this litigation risk. These include client screening, limitation of services, producing high-quality work, and other practice management procedures (See Latham and Linville, 1998 or Demery, 1995b) for a complete discussion). Another tool that can be used to manage litigation risk is professional malpractice insurance.

Malpractice insurance, like all insurance, is used to mitigate catastrophic losses. By paying a smaller, fixed sum, the insured CPA can avoid paying a larger, uncertain amount upon the determination of wrongdoing (Mehr, et al., 1985, 33) The insurance company collects the premium

Readers with comments or questions are encouraged to contact the authors via email.

from the policyholders and then pays the damages to those hurt by the actions of the policyholders.
The insurance company profits from this arrangement by charging premiums high enough to cover the damages that must be paid (Mehr, et al., $1985,663) .^{2}$ This process spreads the risk of litigation across all of the insured practitioners and ultimately, through fees, to the auditor's clients.

Examination of the use of malpractice insurance and the malpractice insurance marketplace can provide valuable knowledge about litigation risk. Insurers have extensive information about claims which can be used to determine the factors associated with litigation risk (Stimpson, 1998). Since insurers use this information to set insurance premiums, some of this knowledge may be revealed by the premium. Also, by examining the insurance choices made by CPA firms and how these choices vary as the perception of litigation risk changes, an understanding of how (or if) malpractice insurance is used to mitigate litigation risk may be gained.

This paper examines two specific issues related to the use of malpractice insurance. First, if legal liability is influenced by state tort provisions, insurance premiums should vary as these legal provisions increase litigation risk. Several 


\section{The Journal of Applied Business Research}

risk factors that affect the insurance premium are examined as controls but this study focuses on the state in which the policyholder operates as a proxy for litigation risk. The second issue examined is how insurance decisions made by the policyholder are influenced by the policyholder's perception of the litigation risk.

Insurance premiums are found to vary directly with the state tort provision alleged to be the most important in audit-related litigation: thirdparty liability standards (AICPA, 1995). Coverage levels, total audit fees, and total fees are also found to influence the premium charged. Further, with the perception of higher litigation risk, the policyholder is willing to pay a higher premium and selects higher levels of coverage. The perception of higher litigation risk has no effect on the choice of deductible levels.

The paper is organized in this fashion. Hypotheses are developed in the next section. The empirical design is discussed in the third section. In that section, necessary controls are developed, the empirical models used to test the hypotheses are formulated, and issues of data collection are discussed. Section four reports the results. The paper concludes with a discussion and then suggestions for further research.

\section{Hypothesis Development}

This study examines two insurance issues. The first issue is an examination of insurance premiums to determine if CPA firms in states with higher litigation risk are paying higher premiums. The second issue is an examination of the insurance choices made by auditors based on their perceptions of the litigation risk.

For the first hypothesis, litigation risk is defined by third-party liability standards. Thirdparty liability standards are used to determine which third parties allegedly damaged by an inappropriate audit report can proceed with a civil lawsuit against the auditor (Miller and Young, 1997). The most restrictive of these standards (and the standard hypothesized to impose the lowest litigation risk on the auditor) is the privity standard which has two general variations. Under
Volume 17, Number 3

a strict privity standard, only the contracting party can sue the auditor for a negligently-performed audit (Pacini and Sinason, 1998). ${ }^{3}$ Near-privity extends the right to bring a civil lawsuit against an auditor for a negligently-performed audit to a clearly-defined primary beneficiary. Although less restrictive than privity, near-privity is still a restrictive third-party standard (Pacini and Sinason, 1998). For the purposes of this study, strict privity and near-privity are considered to be one standard referred to simply as privity. The least restrictive third-party liability standard (and the standard hypothesized to impose the highest litigation risk on the auditor) is the foreseeable standard. Under this standard, any third-party that was reasonably foreseeable by the auditor has the right to sue the auditor for a negligently-performed audit (Miller and Young, 1997).

According to the American Institute of Certified Public Accountants (AICPA, 1995), the two primary legal provisions that affect litigation risk are third-party liability standards and liabilitysharing standards. In the model developed by Linville (2000), third-party liability standards are shown to impose more risk on auditors than liability-sharing standards. In 1991, the year for which data were collected, the six states used in this study had joint and several liability for economic damages. Since the lesser of the two most important standards, the liability-sharing standards, is constant across the six states in this study, it is assumed that the effect of the most important, third-party liability standards, dominates the effect of any other legal standards which might vary across the states.

The foreseeable standard increases the number of parties that can bring a civil action against the auditor which increases the auditor's litigation risk (Lys and Watts, 1994; Nelson, et al., 1988). Consistent with Nelson, et al. (1988), states using a privity standard represent the low-litigation-risk environment and states using a foreseeable standard represent the high-litigation-risk environment. If state tort provisions impose litigation risk on the auditor, it is reasonable to assume that insurance premiums vary directly with litigation risk. This argument suggests the first hypothesis: 
H1: CPA firms in states with higher litigation risk (the foreseeable states) pay higher insurance premiums than CPA firms in states with lower litigation risk (the privity states). ${ }^{4}$

Three hypotheses relate to the choices that a CPA firm faces in determining the appropriate mix of professional malpractice insurance. Once a CPA firm makes a decision to purchase professional malpractice insurance, it must choose the amount of premium that will be paid and the levels of coverage and deductible. Each factor influences the other. For the purpose of developing the hypotheses, the effect of each factor on the other is ignored. The effect of simultaneous estimation in the empirical model is discussed in the next section.

In each of the following hypotheses, the insurance provisions selected are assumed to vary depending on the CPA firm's perception of the litigation risk. Each respondent to the survey is asked to provide their perceptions on the litigation risk in their state along five dimensions. The perceptions of litigation risk on each of the five dimensions are combined to measure the respondent's overall perception of the litigation risk.

If a CPA firm perceives high litigation risk, professional malpractice insurance should be more desirable. In other words, the protection of the insurance is perceived to be more likely to be utilized. As with any other product, if insurance coverage becomes more desirable, the amount that a CPA firm would be willing to pay would increase, ceteris paribus. This suggests:

H2: CPA firms which perceive a higher level of litigation risk are willing to pay a higher premium than CPA firms that perceive a lower level of litigation risk.

As litigation risk is perceived as being higher, higher levels of coverage should be more desirable. As litigation risk increases, auditors are likely to envision higher potential damages for the lawsuits that might be filed. Indeed, the reason that the perceptions of litigation risk may be high is the visibility of the lawsuits in the auditor's state. This visibility usually comes from the large damage amounts associated with the lawsuit but the frequency of lawsuits may also increase the perception of litigation risk. If the frequency of lawsuits increases, the possibility of a CPA firm being involved in multiple lawsuits increases. Higher coverage in this situation is desirable if the multiple lawsuits deplete other sources of damage payments (payments from current revenues, partial liquidation of partnership assets, the use of personal assets, etc.). These suggest the third hypothesis:

H3: CPA firms which perceive a higher level of litigation risk select higher levels of coverage than CPA firms that perceive a lower level of litigation risk.

The perception of litigation risk may also affect the choice of insurance deductible in ways which may lead to the selection of different deductible levels. If the CPA firm is concerned with reducing the amount of premium that must be paid, the auditor would select a higher deductible. On the other hand, if the CPA firm adopts a more global approach to litigation costs and seeks to minimize the total costs, the level of deductible may be set at a lower level. Although the auditor would pay a higher insurance premium immediately, if a claim is made against the insurance policy, the lower deductible would require a smaller out-of-pocket payment later. This strategy reduces total litigation costs if the savings on outof-pocket payments are greater than the increased insurance premium. It is not clear which of these two responses to insurance costs the auditor would adopt. The auditor's response to increased litigation risk may be to increase or to decrease the insurance deductible, suggesting the following hypothesis:

H4: CPA firms which perceive a higher level of litigation risk select a different level of deductible than CPA firms that perceive a lower level of litigation risk.

\section{Empirical Design}

Two different models are estimated, each with a different test variable. The first model (referred to as the premium model) uses the actual 
The Journal of Applied Business Research

third-party liability standards to define the litigation risk. Privity should represent the lowlitigation-risk situation and the foreseeable standard the high-litigation-risk situation. The second model (referred to as the choice model) uses the CPA firms' perceptions to define the litigation risk used to make insurance choices. It is assumed that these perceptions determine the desirability of insurance and thus, are used to make insurance choices. These perceptions about litigation risk can be different than the litigation risk defined by third-party standards.

\section{Model Variables}

Several variables are introduced to control for variation attributable to causes other than the hypothesized ones. These control variables are of two types: the insurance policy parameters and idiosyncratic risk factors of the individual policyholders.

\section{Policy Parameters}

Two insurance policy parameters affect the premium that is charged. The coverage amount determines the upper limit of damages which the insurance company will cover for the policyholder (Mehr, et al., 1985, 207). Any damage amount beyond this cap is the responsibility of the policyholder. As the coverage amount increases, the insurance premium increases to compensate the insurance company who accepts the responsibility for a higher potential payout. The insurance policy also typically contains a deductible amount (Mehr, et al., 1985, 220). This deductible is the amount that must be paid by the policyholder in the event of a claim. This deductible amount is applied to the first dollars of the claim. In such a fashion, a claim less than the deductible amount is the sole responsibility of the policyholder (Mehr, et al., 1985, 222). As the deductible amount is reduced, the insurance company is responsible for a larger amount of the total damage claim which suggests premiums would increase.

Each of these policy parameters are introduced into both models. The premium model uses them as control variables and the choice model uses them as dependent variables for the system
Volume 17, Number 3

of equations because these variables are chosen by the policyholder. Since the choice model utilizes simultaneous estimation, each also acts implicitly as a control on the other dependent variables.

\section{Idiosyncratic Factors}

Identifiable firm characteristics that increase litigation risk are used by the insurance companies to set insurance premiums (Booker, 1973). ${ }^{5}$ Several of these factors are introduced here to control for the idiosyncratic risk posed by each auditing firm. The listing of firm characteristics represents a parsimonious set of the information collected by the insurance carrier during the application process. ${ }^{6}$

The risk of litigation is related to the sheer number of clients for several reasons. As the auditor services a larger number of clients, the amount of attention that can be devoted to each client decreases (Covaleski, 1998). The possibility that one of these clients will feel that the quality of services has fallen below acceptable levels increases. If the possibility of initiating a lawsuit is constant across clients, simply increasing the number of clients mechanically increases the chance that the CPA firm will be sued in any given time period. Also, increasing the number of clients likely increases the diversity of the client portfolio. As this diversity increases, the challenges to the auditor to know about the reporting standards, accounting practices, and other clientor industry-specific items increase (Covaleski, 1998). As the number of clients increase, client screening and evaluation becomes more difficult. This increases the chance that a CPA firm accepts or retains a client that it should not have. Finally, as discussed earlier, if the number of clients increase, the number of audit report users increase expanding the auditor's litigation risk (Nelson, et al., 1988). For all these not-mutually-exclusive reasons, the number of clients should increase the litigation risk and as a result, a control variable for the number of clients is introduced into each model.

The size of the audit clients could also affect the auditor's litigation risk (Murray, 1992, 68). 
Larger organizations are likely to have more parties that rely upon the auditor's report. If a substandard audit is performed, a larger client is likely to have more parties that are economically damaged by reliance on the audit report. This larger pool of injured parties increases the auditor's litigation risk for two reasons. Anyone of these injured parties could possibility initiate a civil lawsuit to recover damages increasing the probability of such a lawsuit. ${ }^{7}{ }^{8}$ Also because of the larger number of injured parties, the potential level of damages is higher. For these reasons, the total audit fees are introduced into each model as a control. ${ }^{9}$

The defendant auditor's ability to pay could also affect the possibility of lawsuits (the 'deep pockets' problem) (Alexander, 1991). One measure of the ability to pay would be the total firm revenues. In other words, although the CPA firm is being sued for audit malfeasance, the revenues from tax, consulting, write-up, or other services may be used to pay the damages. Total revenues are likely to be positively correlated to insurance coverage and provide the plaintiff an indication of the CPA firm's total ability to pay. To the extent that the total revenues increase the probability of a lawsuit, insurance premiums should increase. For this reason, total revenues are introduced into the premium model as a control variable since the initiation of a lawsuit increases the chances that the insurance company will have to pay damages.

Ability to pay is also introduced into the choice model as a control variable. The plaintiff has the three primary sources of damages from the defendant: insurance payments, payments from the firm, and payments from the principals' personal assets. The CPA firm's primary concern in risk management is likely to protect personal assets. An organizational form that protects personal assets should affect insurance choices. At the time of the survey, respondents had the option of organizing as a partnership or a professional corporation which in certain cases could provide very limited protection of personal assets. ${ }^{10}$ Since it could affect the ability to pay and may be viewed by the potential policyholder as partial protection against litigation risk, organizational form is introduced into the choice model as a con- trol variable.

The number of CPAs in the auditing firm is also likely to increase litigation risk. Each CPA can perform an act which results in a lawsuit. The more CPAs in a firm the greater the likelihood that one of them will perform negligently. A larger number of CPAs also increases the difficulty of control within the CPA firm. As quoted in Demery (1995a, 68), the manager of Cal Accountants Insurance Co. (or CAMICO) stated: "Everyone in the firm can potentially add to liability." As a result, the number of CPAs in the firm is entered as a control variable into each model.

\section{Test Variables}

The test variable in the premium model is the indicator variable for the state's litigation risk. If the state uses foreseeability (privity) as the thirdparty liability standard, the litigation risk is assumed to be high (low) and the indictor variable is coded $1(0)$.

The test variable in the choice model is the perception of the CPA firm about the litigation risk. Five survey questions are asked to measure perceptions about the litigation risk. The responses are combined into one summary measure of litigation risk.

\section{Models}

The premium model is used to test hypothesis one. The amount of the insurance premium is the dependent variable. The third-party liability standards are used to determine the litigation risk which is the test variable. The premium model:

The coefficient of each variable in the premium model is predicted to be positive except for the coefficient on the deductible variable which is predicted to be negative. No prediction is made about the intercept.

The choice model is a simultaneousequations model. The insurance premium that the CPA firm is willing to pay, the coverage level desired, and the deductible desired are simultaneously determined and are the dependent va- 
riables in the equations of the simultaneousequations model. The significance of the coefficient on the test variable, perception of risk, is used to test hypotheses two through four. The choice model:

The coefficient on each variable in the choice model is predicted to be positive except for the coefficient on the perception of risk variable in equation three which has no predicted sign. No predictions are made about the intercept.

\section{Data Collection}

Data were collected by survey in late 1993 and early 1994. The names of CPA firms with five to twelve CPAs located in selected states were obtained from the American Institute of Certified Public Accountants. Six states were selected because either privity (New York, Kansas, Illinois) or foreseeability (New Jersey, California, Wisconsin) was used in 1991 to determine thirdparty liability. All information was collected for the year of 1991, a year in which no major changes were made in these states' audit-related tort provisions.

Eight hundred and twenty-eight surveys were mailed and 207 were returned for an overall response rate of $25 \%$. This response rate compares with other reported response rates (Quint, 1995; Thompson and Henry, 1991). Failure to respond to all questions reduced the sample for this study to 148. Obviously, any CPA firm not carrying malpractice insurance (going 'bare') cannot be part of this sample since the firm would have no policy-related data. Forty-three (43) firms in the sample did not carry malpractice insurance and 16 firms were dropped from the final sample for failing to provide other necessary information.

\section{Results}

premium $=$

coverage $=$
In the overall sample, $21 \%(\mathrm{n}=43)$ of the CPA firms report that they carry no malpractice insurance. This rate is comparable to the findings of Quint (1995) who reports that 28\% of the CPA firms with less than $\$ 500,000$ in revenues go 'bare'. Thompson and Henry (1991) find that $35.7 \%$ of CPA firms with annual revenues less than $\$ 1$ million have no malpractice insurance but this rate drops to $15.8 \%$ for firms with between $\$ 1$ million and \$5 million in annual revenues and to $0 \%$ for firms with between $\$ 5$ million and $\$ 25$ million in annual revenues. Since the average revenues of the firms in this sample is $\$ 1.6$ million, the reported rate of uninsured CPA firms in this sample is comparable to Thompson and Henry's finding. Wolosky (1995) reports a considerably higher percentage of uninsured CPA firms at $47 \%$.

Table 1 reports the results of the ordinaryleast-squares estimation of the premium model. This is a test of hypothesis one which predicts that insurance premiums will be higher in states with a foreseeable standard of third-party liability than in the states with a privity standard. The coefficients on the control variables of coverage $(p<0.0000)$, audit fees $(p=0.0934)$, and total fees $(p<0.0000)$ are significant. The coefficients on the control variables of deductible $(p=$ $0.6635)$, number of clients $(p=0.4286)$, and number of CPAs $(p=0.1075)$ are not significant at conventional levels. The overall model is significant $(p<0.001)$.

Insert Table 1 here

The coefficient on the litigation risk variable is highly significant $(p=0.0122)$. Auditors in states with the less restrictive third-party standard pay higher malpractice insurance premiums after controlling for coverage, deductible, and idiosyncratic factors. This result suggests that actuaries view a less restrictive third-party liability stan-

Equation one:

$$
\begin{aligned}
& \left.\mathrm{b}_{0}+\mathrm{b}_{1} \text { (organizational form }\right)+\mathrm{b}_{2}(\text { CPAs })+\mathrm{b}_{3}(\log \text { of audit billings }) \\
& +\mathrm{b}_{4}(\text { perception of risk })+\mathrm{e} \\
& \text { Equation two: } \\
& \mathrm{b}_{0}+\mathrm{b}_{1}(\text { organizational form })+\mathrm{b}_{2}(\text { CPAs })+\mathrm{b}_{3}(\log \text { of audit billings }) \\
& +\mathrm{b}_{4}(\text { perception of risk })+\mathrm{e}
\end{aligned}
$$


The Journal of Applied Business Research

dard as imposing a higher litigation risk on auditors. Hypothesis one is strongly supported.

Table 2 reports the results of the regressions on the insurance-choice decisions. A three-stageleast-squares estimation is used. The coefficient on the control variable of the number of CPAs is significant in all three equations ( $p$-values range from less than 0.0000 to 0.0024 ). The coefficient on the control variable of organizational form does not achieve significance in any of the three equations. The coefficient on the control variable of audit billings achieves significance in the premium equation $(p=0.0764)$ but not in the other equations.

Insert Table 2 here

The coefficient on the test variable, perception of litigation risk, achieves significance in two of the three equations. The overall system of equations in the model is highly significant $(p<$ $0.001)$.

In equation one where premium is the dependent variable, the coefficient on the perception of litigation risk is highly significant $(p=0.0099)$. This suggests that as CPA firms perceive a higher litigation risk, they are willing to bear a higher premium. This result can be interpreted in this fashion. As litigation risk increases, professional malpractice insurance is more valuable to the policyholder and as a result of this greater value, a higher premium can be tolerated. Hypothesis two is strongly supported.

The coefficient on the perception of litigation risk variable is significant $(p=0.0495)$ in equation two where coverage is the dependent variable. This suggests that as the perception of litigation risk increases, the auditor opts for higher insurance coverage. Hypothesis three is supported.

The third equation in the system is used to test hypothesis three which predicts a different deductible as the perception of litigation risk increases. The coefficient on the perception of litigation risk variable is not significant $(p=0.7642)$. Hypothesis four is not supported which suggests
Volume 17, Number 3

that the amount of deductible selected is not influenced by the perception of risk.

\section{Conclusion and Discussion}

This study examines the use of professional malpractice insurance by CPA firms to limit their litigation exposure. Specifically, insurance premiums are examined to determine the factors which insurance companies feel are associated with litigation risk. Also, this study examines how the use of malpractice insurance is influenced by the CPA firms' perception of litigation risk.

The premium charged auditors for malpractice insurance is found to be significantly influenced by the level of coverage, the amount of audit fees, the amount of total fees, and the state in which the policyholder practices. The policyholders in states with a foreseeable standard of thirdparty liability are charged a higher premium, after controlling for other fee-influencing factors, than policyholders in states with a privity standard of third-party liability.

A system of simultaneous equations is used to examine the change in insurance choices associated with a change of perceptions of litigation risk. The system of simultaneous equations is used to allow for simultaneous selection of a premium level, coverage level, and deductible level. CPA firms who perceive higher levels of litigation risk are more tolerant of bearing high insurance premiums. In other words, if the potential benefits are perceived to be high enough, higher premium costs can be borne. CPA firms who perceive a higher litigation risk select higher coverage levels. Intuitively, as more risk is perceived, the auditor becomes more sensitized to litigation concerns and the advantages of higher insurance coverage become more apparent. The deductible is not sensitive to changes in the perceptions of litigation risk. Overall, these results are consistent with the use of malpractice insurance as a tool to mitigate litigation risk.

\section{Suggestions for Future Research}

Several extensions to this study remain. A more comprehensive examination of the setting of insurance premiums would contribute greatly to the understanding of litigation risk factors. A 
The Journal of Applied Business Research

model to establish the determinants in setting an insurance premium would provide a glimpse into the actuaries' understanding of the factors associated with litigation risk. Another line of research would examine the interaction between the use of insurance and the use of other litigationreduction techniques. The use of insurance in the new forms of limited-liability organizations now available to the CPA would be an example of this type of inquiry.

\section{Endnotes}

1. I would like to thank Yoram Barzel, Dave Burgstahler, Jim Jiambalvo, Steve Sefcik, Naomi Soderstrom, and the participants of the Northwest Accounting Research Group for their helpful comments. I would like to thank CPAs Ron Bishop, Steve Flerchinger, and Larry Lucas for their comments on the survey instrument. Any remaining errors are my own.

2. Commonly, an insurance company generates profits by two means: underwriting profits and portfolio profits (Mehr, et al., 1985, 699). The underwriting profits (described above) are contingent upon insurance premiums exceeding damage awards that must be paid. Portfolio profits come from the investment earnings on the asset reserves held by the insurance company. These asset reserves are created by underwriting profits in earlier years which have not been paid out as distributions to investors or claimants (Mehr, et al., 1985, 691). If underwriting profits decline and premiums cannot be adjusted, the insurance company should exit this segment of the underwriting business. This phenomenon occurred in the market for malpractice insurance for accountants in the 1980s (McDonald, 1995).

3. If the auditor's malfeasance is alleged to be more serious than ordinary negligence (gross negligence or fraud), third-party liability standards are not applicable. All damaged parties can bring a civil lawsuit when these more serious forms of malfeasance are alleged.

4. All hypotheses are stated in the alternative form. Necessary controls are discussed in the
Volume 17, Number 3

next section.

5. The typical malpractice insurance application form is four to six pages long (before supplemental forms) and asks many detailed questions. Since data processing is costly, it is assumed that each question helps identify a factor that has been shown by actuaries to be associated with litigation risk.

6. Few respondents reported any prior claims on their insurance policies for audit-related incidents. Since there is little or no variation in this variable, it is not added to the model. Its inclusion does not change the reported results.

7. The larger number of allegedly-damaged parties also makes class-action provisions more advantageous to the plaintiff further increasing the probability of a lawsuit.

8. Whether or not a damaged party can (or will) bring a lawsuit depends on many factors. One important factor, third-party liability standards, was discussed earlier.

9. Since a linear relationship between the dependent variables and the size variables of total audit fees and total fees is unlikely, the natural logs of each size variable are used.

10. CPA firms today have more options in organizational form than they did in 1991, the time from which the data was collected.

\section{References}

1. Alexander, J. C., "Do The Merits Matter? A Study Of Settlements In Security Class Actions," Stanford Law Review (February), pp. 497-598, 1991.

2. American Institute of Certified Public Accountants (AICPA), Implementing a Legal Liability Gap Analysis Study, American Institute of Certified Public Accountants: New York, New York, 1995.

3. Booker, J.A., "Relative Risk Evaluation: A Supplement To Professional Liability Insurance," The National Public Accountant (May), pp. 18-25, 1973.

4. Covaleski, J. M., "Insurance Prices Ease, As Risks Rise," Accounting Technology 14 (2) (Supplement), pp. 3-7, 1998.

5. Demery, P., "Slaying The Liability Dragon," The Practical Accountant 28 (4), pp. 67-73, 
1995a.

6. Demery, P., "Malpractice Insurance: Getting

The Right Fit," The Practical Accountant (August), pp. 28-38, 1995b.

7. Latham, C. K., and Linville, M., "A Review of the Literature in Audit Litigation," Journal of Accounting Literature 17, pp. 175-213, 1998.

8. Linville, M., "A Comparison Of Legal Standards And Their Influence On Damage Calculations In Audit Litigation," working paper, Washington State University, 2000.

9. Lys, T., and Watts, R., "Lawsuits Against Auditors," Journal of Accounting Research 32 (Supplement), pp. 65-93, 1994.

10. McDonald, J.O., "Accountants' Risk Add Up To Opportunity Or Disaster," Best's Review (November), 76-7, 1995.

11. Mehr, R. I., Cammack, E., and Rose, T., Principles of Insurance. Richard D. Irwin, Inc.: Homewood, Illinois, 1985.

12. Miller, R. and Young, M., "Financial Reporting And Risk Management In The $21^{\text {st }}$ Century," Fordham Law Review 65, pp. 19872064, 1997.

13. Murray, M.F., Managing the Malpractice Maze, American Institute of Certified Public Accountants: New York, New York, 1992.

14. Nelson, J., Ronen, J., and White, L., "Legal Liabilities And The Market For Auditing Services," Journal of Accounting, Auditing, and Finance 3, pp. 255-295, 1988.

15. Pacini, C., and Sinason, D., "Gaining A New Balance In Accountants' Liability To Nonclients For Negligence: Recent Developments And Emerging Trends," Commercial Law Journal 103 (1), pp. 15-66, 1998.

16. Palmrose, Z., "Audit Litigation Research: Do The Merits Matter? An Assessment And Directions For Future Research," Journal of Accounting and Public Policy 16, pp. 335378, 1997.

17. Quint, L.F., "Managing Your Practice Today," CPA Journal 65 (8), pp. 69-71, 1995.

18. Stimpson, J., "Changing Your Malpractice Insurance," The Practical Accountant 31(7), pp. 27-32, 1998.

19. Thompson, J.H. and Henry, L. J., "Professional Liability Insurance: Go Bare Or Not?," Journal of Accountancy 172 (1), pp. 111-6,
1991.

20. Wolosky, H., "Tax Prep In No. 1 Source Of Income: Public Accountants Underinsured," The Practical Accountant 28 (2), 9, 1995. 